\title{
Pelayanan Jasa Keperawatan: Tingkat Kepuasan Pasien pada Unit Rawat Inap Rumah Sakit Umum "dr. Slamet" Garut
}

\author{
Lindayani \\ Universitas Garut \\ Jalan Jati 42B Tarogong Kaler \\ lindayani@uniga.ac.id
}

\begin{abstract}
Abstrak-Tujuan penelitian ini adalah untuk mengetahui pelayanan jasa keperawatan Unit Rawat Inap Intan Sartika Rumah Sakit Umum "dr. Slamet" Garut, mengetahui tingkat kepuasan ditinjau dari kesenjangan antara kinerja pelayanan dan harapan pasien pada Unit Rawat Inap Intan Sartika Rumah Sakit Umum "dr. Slamet" Garut, mengetahui pengaruh pelayanan jasa keperawatan terhadap tingkat kepuasan pasien pada Unit Rawat Inap Intan Sartika Rumah Sakit Umum "dr. Slamet" Garut. Metode penelitian yang digunakan adalah metode deskriptif analisis, sedangkan data yang diperlukan dalam penelitian diperoleh dari observasi dan penyebaran angket kepada pasien. Berdasarkan hasil penelitian maka ditarik kesimpulan bahwa tingkat kepuasan pasien ditinjau dari kesenjangan antara kinerja pelayanan dan harapan tingkat kepuasan pasien yang dirawat di Unit Rawat Inap Intan Sartika RSU dr.Slamet Garut secara keseluruhan adalah baik. Berdasarkan kesimpulan diatas, maka disarankan kepada pihak Unit Rawat Inap Intan Sartika RSU dr. Slamet Garut untuk meningkatkan daya tanggap terhadap keluhan pasien, memberikan informasi dengan bahasa yang sederhana dan mudah dimengerti, meningkatkan kecakapan tenaga medis dengan mengadakan pendidikan dan pelatihan rutin, meningkatkan keamanan dan kepercayaan pasien, Meningkatkan Keterampilan providerjasa dalam berkerja, seperti pengetahuan dalam menggunakan alat-alat diagnosa penyakit. meningkatkan Kesopanan dan keramahan penyedia jasa meningkatkan intensitas pertemuan dan komunikasi dengan pasien dan keluarganya.
\end{abstract}

Kata Kunci- Pelayanan Jasa Keperawatan, Kepuasan Pasien

Abstract-The present study looks at in-patient nursing service at Garut Regional Public Hospital dr. Slamet and patient satisfaction as viewed from the gap between service performance and patient expectations. Using a descriptive approach, the influence of in-patient nursing service on patient satisfaction was analyzed. Research data were collected through observation and questionnaires addressed to the patients. The results of the study lead to a conclusion that patients were satisfied with the in-patient nursing care they received. It is suggested that the hospital improve their responsiveness to patient complaints, provide information in simple and easy to understand language, improve the skills of medical personnel by providing regular education and training, improve patient safety and trust, improve service personnel skills such as knowledge in using disease diagnostic tools, hospitality skills, and communication skills.

Keyword: In-Patient Nursing Service, Patient Satisfaction

\section{PENDAHULUAN}

Lembaga kesehatan seperti halnya rumah sakit disamping mengemban misi sosial, dewasa ini sudah mulai semakin dituntut untuk mampu berperan sebagai lembaga yang lebih mandiri melalui kemampuan dalam memperoleh pendapatan dari aktivitasnya dalam menyediakan layanan kesehatan yang memuaskan masyarakat [1]. Pada umumnya pengelolaaan rumah sakit umum di Indonesia dewasa ini adalah pihak pemerintah dan pihak swasta yang cara pengelolaannya pun berbeda. Semua aktivitas atau kegiatan rumah sakit yang dikelola oleh pemerintah sebagian dananya disubsidi dari pemerintah dan sebagian lagi dibiayai oleh pendapatan yang diperoleh rumah sakit. Tidak semua rumah sakit umum yang dikelola oleh pemerintah memperoleh pendapatan yang tinggi untuk memenuhi segala kebutuhannya misalnya kebutuhan dalam menyediakan peralatan kesehatan berteknologi tinggi, sumber daya manusia yang andal, semuanya itu memerlukan biaya yang tinggi. Hal ini akan terkait dengan pelayanan jasa yang diberikan rumah sakit kepada pasiennya. Jika sumber daya tersebut kurang memadai maka harapan pasien akan kebutuhan kesehatannya tidak akan terpuaskan [2]. Namun sebaliknya rumah sakit umum yang dikelola oleh swasta atau pun pihak asing, semua biaya untuk memenuhi kebutuhannya dibebankan kepada para pasien yang telah menggunakan layanan rumah sakit tersebut. Para pasien yang menggunakan layanan rumah sakit tersebut biasanya mempunyai kemampuan yang tinggi untuk membayar biaya atas layanan yang diterimanya [3]. Oleh karena itu kepuasan pasienpun akan tercapai.

Selain itu rumah sakit harus pula memperhatikan pelayanan terhadap staf dan para medis yang berkerja di rumah sakit, hal ini diperlukan untuk mencegah timbulnya ketidakpuasan yang mengakibatkan terjadinya hal yang merugikan, baik untuk pihak 
rumah sakit maupun pasien [4]. Misalnya demo yang dilakukan oleh tenaga medis yang menuntut hak atas pekerjaan mereka. Dengan adanya pemahaman mengenai pelayanan baik terhadap pasien maupun staf, diharapkan kinerja pelayanan rumah sakit akan meningkat dimasa yang akan dating [5]. Meningkatkan kepuasan pasien pada era bisnis adalah tuntutan yang harus dilaksanakan dan diharapkan dapat memberikan sumbangan yang positif bagi pihak rumah sakit. Rumah sakit akan memiliki citra yang baik di mata masyarakat dan unggul dalam persaingan. Begitu pula masyarakat (pasien) menjadi loyal karena merasa harapan dan kebutuhan akan sarana kesehatan dapat terpuaskan [6].

Berdasarkan penelitian terdahulu diduga terdapat kesenjangan negatif antara pelayanan yang diberikan oleh Unit Rawat Inap Intan Sartika dan kepuasan yang dirasakan oleh pasien. Hal ini dapat dilihat dari keterbatasan ruangan yang dimiliki sehingga pasien harus menunggu lama untuk mendapatkan pelayanan medik di ruang Unit Rawat Inap Intan Sartika. Peralatan teknologi kedokteran yang dapat membantu diagnosa penyakit pun masih terbatas. Selain itu penyedia jasa keperawatan masih kurang tanggap dalam menangani keluhan pasiennya. Dari hal tersebut Penyusun tertarik untuk mengetahui lebih lanjut tentang pelayanan yang diberikan oleh Unit Rawat Inap Intan Sartika Rumah sakit Umum "dr. Slamet" Garut dan tingkat kepuasan pasien yang menggunakan layanan Unit Rawat Inap Intan Sartika Rumah sakit Umum "dr. Slamet" Garut.

Berdasarkan uraian diatas maka perlu melakukan penelitian tentang pelayanan jasa keperawatan dan pengaruhnya terhadap tingkat kepuasan pasien sehingga melalui penelitian ini diharapkan dapat dijadikan bahan evaluasi dan sekaligus menggali temuan-temuan di lapangan yang dapat dijadikan sumber dalam meningkatkan kepuasan pasien melalui perbaikan-perbaikan pelayanannya.

\section{KAJIAN PUSTAKA}

Pengertian pelayanan menurut Moenir (2001:16) adalah "Pelayanan adalah proses pemenuhan kebutuhan melalui aktivitas orang lain yang langsung". Sedangkan pengertian pelayanan menurut E. Juhana Wijaya (1999:36) adalah "Pelayanan adalah salah satu usaha untuk membantu menyiapkan (mengurus) apa yang diperlukan orang lain."

Dari kedua pengertian diatas dapat diambil kesimpulan bahwa pelayanan adalah salah satu cara untuk membantu kegiatan atau aktivitas orang lain untuk mencapai tujuan tertentu [7].
Perwujudan Pelayanan

Secara umum sebagai pihak yang ingin memperoleh pelayanan yang baik dan memuaskan, maka perwujudan pelayanan yang di dambakan ialah [8]:

1) Adanya kemudahan dalam pengurusan kepentingan dengan pelayanan yang cepat dalam arti tanpa hambatan yang kadang-kala dibuat-buat.

2) Memperoleh pelayanan secara wajar tanpa gerutu, sindiran, atau untaian kata lain semacam itu yang nadanya mengarah pada permintaan sesuatu, baik dengan alasan dinas (pembelian kertas, ganti ongkos foto kopi, atau alasan untuk kesejahteraan.

3) Mendapatkan perlakuan yang sama dalam pelayanan terhadap kepentingan yang sama , tertib dan tidak pandang "bulu". Artinya kalau memang untuk pengurusan permohonan itu harus antri secara tertib, hendaknya semuanya diwajibkan antri sebagaimana yang lain, baik antri secara fisik maupun antri masalahnya.

4) Pelayanan yang jujur dan terus terang, artinya apabila ada hambatan karena suatu masalah yang tidak dapat dielakan hendaknya diberitahukan, sehingga orang tidak menunggu-nunggu sesuatu yang tidak menentu. Dengan pemberitahuan orang dapat mengerti dan akan menyesuaikan diri secara ikhlas tanpa emosi.

Keempat hal itulah yang menjadi dambaan setiap orang yang berurusan dengan badan/instansi yang bertugas melayani masyarakat. Menurut Moenir apabila hal itu dapat dipenuhi masyarakat akan puas, dan dampak kepuasan masyarakat terlihat pada [9]:

1) Masyarakat sangat menghargai kepada korps pegawai yang bertugas dibidang pelayanan umum. Mereka tidak memandang "remeh" dan mencemooh korps itu dan tidak pula berlaku sembarangan.

2) Masyarakat terdorong mematuhi aturan dengan penuh kesadaran tanpa prasangka buruk, sehingga lambat laun dapat terbentuk sistem pengendalian diri (self control) yang akan sangat efektif dalam ketertiban berpemerintahan dan bernegara.

3) Ada rasa bangga pada masyarakat atas karya korps pegawai di bidang layanan umum, meskipun dilain pihak ada yang merasa ruang geraknya dipersempit karena tidak dapat lagi "mempermainkan mereka". Rasa bangga itu akan membawa dampak positif terhadap usaha mempertahankan citra korps pegawai yang tangguh, tanggap dan disiplin.

4) Kelambatan-kelambatan yang "biasa" ditemui dapat dihindarkan dan ditiadakan. Sebaliknya akan 
dapat ditumbuhkan percepatan kegiatan di masyarakat di semua bidang kegiatan baik ekonomi, sosial maupun budaya [10].

5) Karena adanya kelancaran dibidang pelayanan umum, gairah usaha dan inisiatif masyarakat akan meningkat, yang akan meningkatkan pula usaha pengenbangan ipoleksosobud masyarakat ke arah tercapainya masyarakat yang adil dan makmur berlandaskan pancasila.

\section{METODE PENELITIAN}

Berdasarkan variabel-variabel yang diteliti, maka jenis penelitian ini yaitu penelitian deskriptif dan verifikatif. Penelitian verifikatif merupakan penelitian yang dilaksanakan untuk menguji kebenaran ilmuilmu yang telah ada, berupa konsep, prinsip, prosedur, dalil maupun praktek dari ilmu itu sendiri, sehingga tujuan dari penelitian verifikatif dalam penelitian ini untuk memperoleh kebenaran dari sebuah hipotesis yang dilaksanakan melalui pengumpulan data di lapangan, mengenai pengaruh pelayanan jasa terhadap tingkat kepuasan pasien yang menggunakan layanan Unit Rawat Inap Intan Sartika Rumah Sakit Umum dr. Slamet Garut. Jenis data yang digunakan dalam penelitian ini adalah data sekunder. Populasi dalam penelitian ini adalah para pasien yang menggunakan layanan Unit Rawat Inap Intan Sartika Rumah Sakit Umum dr. Slamet Garut. Ukuran sampel minimal dalam penelitian ini adalah 106 responden. Teknik analisis data yang digunakan adalah regresi liniear sederhana dengan alat bantu software komputer Statistical Product for Service Solutions (SPSS) 24.0 for windows.

\section{HASIL DAN PEMBAHASAN}

Variabel bebas dalam penelitian ini yaitu pelayanan jasa (X) sedangkan untuk variabel terikatnya adalah kepuasan pasien (Y). Untuk menguji ada tidaknya pengaruh bebas terhadap variabel terikat, dilakukan dengan pengujian regresi sederhana.

Dengan menggunakan program SPSS 24.0 for wondows, diperoleh hasil koefisien regresi sebagai berikut.

Tabel 1. Model Regresi Linear Sederhana

Pelayanan jasa Terhadap Kepuasan pasien

\begin{tabular}{|c|c|c|c|c|c|}
\hline \multicolumn{6}{|c|}{ Coefficients $^{\mathrm{a}}$} \\
\hline \multirow{4}{*}{\begin{tabular}{ll}
\multicolumn{2}{l}{ Model } \\
1 & (Constant) \\
& Pelayanan \\
& Jasa
\end{tabular}} & \multicolumn{2}{|c|}{$\begin{array}{l}\text { Unstandardized } \\
\text { Coefficients }\end{array}$} & $\begin{array}{l}\text { Standardized } \\
\text { Coefficients }\end{array}$ & \multirow[b]{2}{*}{$\mathrm{t}$} & \multirow[b]{2}{*}{ Sig. } \\
\hline & B & Std. Error & Beta & & \\
\hline & 16,791 & 4,514 & & 3,720 &, 000 \\
\hline & ,485 & ,038 & ,780 & 12,707 & ,000 \\
\hline a. Dependent & able: Pe & ayanan Jasa & & & \\
\hline
\end{tabular}

Berasarkan Tabel 1 pada kolom B, tercantum nilai konstanta dan nilai koefisien regresi linear sederhana untuk variabel bebas. Berdasarkan nilai-nilai itu maka dapat ditentukan model regresi linear sederhana yang dinyatakan dalam bentuk persamaan sebagai berikut:

$$
\begin{gathered}
Y=\mathbf{a + b X} \\
Y=16,791+0,485 X
\end{gathered}
$$

Berdasarkan persamaan regresi linier sederhana di atas, nilai konstanta sebesar 16,791 menyatakan bahwa jika tidak ada pelayanan jasa, maka besarnya kepuasan pasien 16,791. Koefisien regresi pada variabel pelayanan jasa adalah 0,485 yang artinya setiap terjadi peningkatan nilai pelayanan jasa akan terjadi peningkatan kepuasan pasien sebesar 0,485. Sebaliknya jika terjadi penurunan kepuasan pasien, pelayanan jasa akan menurunkan customer swithing behavior sebesar 0,485 satu satuan nilai. Dapat dikatakan bahwa pelayanan jasa dalam Unit Rawat Inap Intan Sartika RSU dr. Slamet Garut akan berpengaruh terhadap tingkat tingkat kepuasan pasien. Jika pelayanan jasa kurang kondusif, maka kepuasan pasien akan rendah.

Analisis koefisien determinan digunakan untuk mengetahui persentase pengaruh yang terjadi dari variabel bebas terhadap variabel terikat. Sehingga dalam penelitian ini koefisien determinan digunakan untuk mengetahui besarnya persentase pengaruh $\mathrm{X}$ terhadap Y.

Tabel 2. Koefisien Determinasi Dari Pelayanan jasa Terhadap Kepuasan pasien

\begin{tabular}{lcccc}
\hline \multicolumn{4}{c}{ Model Summary $^{\mathbf{b}}$} \\
\hline Model & $\mathrm{R}$ & R Square & $\begin{array}{c}\text { Adjusted R } \\
\text { Square }\end{array}$ & $\begin{array}{c}\text { Std. Error of the } \\
\text { Estimate }\end{array}$ \\
1 &, $780^{\text {a }}$ &, 608 &, 604 & 7,883 \\
\hline $\begin{array}{l}\text { a. Predictors: (Constant), Pelayanan jasa } \\
\text { b. Dependent Variable: Kepuasan pasien }\end{array}$
\end{tabular}

Sumber:Hasil Pengolahan data 2019

Berikut adalah hasil perhitungan koefisien determinasi dari X terhadap Y:

$$
\begin{aligned}
\mathrm{KD} & =r^{2} \times 100 \% \\
& =r^{2} \times 100 \% \\
& =(\mathbf{0 , 7 8 0})^{2} \times 100 \% \\
& =0,608 \times 100 \% \\
& =\mathbf{6 0 , 8 \%}
\end{aligned}
$$

Dari hasil penghitungan koefisien determinasi untuk pelayanan jasa (X) terhadap kepuasan pasien (Y) adalah 60,8\%, dengan kata lain kepuasan pasien kuat dipengaruhi $60,8 \%$ oleh pelayanan jasa sedangkan $39,2 \% \%$ dipengaruhi oleh faktor-faktor yang tidak diteliti di penelitian ini. 
Untuk menguji signifikansi pelayanan jasa berpengaruh terhadap kepuasan pasien dapat digunakan uji t, yaitu dengan membandingkan antara $t_{\text {hitung dan }} t_{\text {tabel }}$. Rumus uji $\mathrm{t}$ atau uji coefficients dijelaskan pada Tabel 4.29 sebagai1berikut.

Tabel 3. Nilai Signifikansi Uji T Pelayanan jasa

Berpengaruh Terhadap Kepuasan pasien

\begin{tabular}{|c|c|c|c|c|c|}
\hline \multicolumn{6}{|c|}{ Coefficients $^{\mathrm{a}}$} \\
\hline \multirow{4}{*}{$\begin{array}{l}\text { Model } \\
1 \text { (Constant) } \\
\quad \text { Pelayanan } \\
\text { jasa }\end{array}$} & \multicolumn{2}{|c|}{$\begin{array}{l}\text { Unstandardized } \\
\text { Coefficients }\end{array}$} & \multicolumn{3}{|l|}{$\begin{array}{c}\text { Standardized } \\
\text { Coefficients }\end{array}$} \\
\hline & B & Std. Error & Beta & $\mathrm{t}$ & Sig. \\
\hline & 16,791 & 4,514 & & 3,720 &, 000 \\
\hline & ,485 & ,038 & ,780 & 12,707 & ,000 \\
\hline
\end{tabular}

Sumber:Hasil Pengolahan data 2018

Tabel 3 menunjukan pengujian untuk uji t yang diambil dari Coefficients dengan menggunakan uji $\mathrm{t}$ yaitu $t_{\text {hitung }}>t_{\text {tabel }}$. Maka $t_{\text {tabel }}$ dengan 106 responden yaitu pada $\mathrm{a}=0,05$ adalah 1,65964. Sehingga didapat 12,707 $>$ 1,65964, maka $\mathrm{H}_{\mathrm{o}}$ ditolak. Kesimpulannya sama dengan pengujian yang dilakukan dengan menggunakan nilai probabilitas. Dengan demikian dapat disimpulkan bahwa hipotesis dalam penelitian ini yaitu $\mathrm{H}_{\mathrm{o}}$ ditolak dan $\mathrm{H}_{\mathrm{a}}$ diterima, sehingga terdapat pengaruh antara pelayanan jasa terhadap kepuasan pasien pada Unit Rawat Inap Intan Sartika RSU dr. Slamet Garut.

Berdasarkan hasil penelitian yang bersifat empiris yaitu pelayanan jasa terhadap kepuasan pasien. Pelayanan jasa dipengaruhi oleh customer sitching behavior. Besarnya pengaruh pelayanan jasa terhadap kepuasan pasien adalah sebesar $60,8 \%$. Pelayanan jasa berpengaruh terhadap kepuasan pasien mengingat pelayanan jasa merupakan biaya atau beban yang harus ditanggung oleh pasien selama proses perpindahan dari suatu produk atau jasa ke produk atau jasa yang lain. Pada hasil penelitian menunjukan bahwa pelayanan jasa berpengaruh terhadap kepuasan pasien. Hal ini menunjukan bahwa pelayanan jasa berpengaruh untuk menurunkan kepuasan pasien. Sehingga perlu rasanya bagi Unit Rawat Inap Intan Sartika RSU dr. Slamet Garut untuk meningkatkan kepercayaan pasien. Unit Rawat Inap Intan Sartika RSU dr. Slamet Garut dapat meningkatkan kepuasan pasien dengan meningkatkan layanan yang mereka sediakan dengan produk atau layanan. Pergeseran perilaku membantu dalam membuat hubungan antara pasien dan Unit Rawat Inap Intan Sartika RSU dr. Slamet Garut. Namun Unit Rawat Inap Intan Sartika RSU dr. Slamet Garut perlu melakukan analisis dimana letak kelebihan serta kelemahan dari masing-masing variabel tersebut. Unit Rawat Inap Intan Sartika RSU dr. Slamet Garut perlu lebih meningkatkan kualitas produk dan jasanya agar pasien tidak merasa kecewa dan berhenti berlangganan dan akhirnya pasien akan beralih pada Unit Rawat Inap Intan Sartika RSU dr. Slamet Garut lain.

\section{KESIMPULAN DAN SARAN}

Berdasarkan hasil penelitian yang telah dilakukan, tingkat kepuasan pasien ditinjau dari kesenjangan antara kinerja pelayanan dan harapan tingkat kepuasan pasien yang dirawat di Unit Rawat Inap Intan Sartika RSU dr. Slamet Garut secara keseluruhan kepuasan pasien kuat dipengaruhi 60,8\% oleh pelayanan jasa sedangkan $39,2 \%$. Hal ini berarti pelayanan jasa memiliki pengaruh yang positif dan signifikan terhadap customer pelayanan jasa dengan pengaruh kuat. Hal ini menunjukkan bahwa semakin tinggi pelayanan jasa yang dilakukan Unit Rawat Inap Intan Sartika RSU dr. Slamet Garut, maka semakin berkurang pasien Unit Rawat Inap Intan Sartika RSU dr. Slamet Garut untuk beralih pada Unit Rawat Inap Intan Sartika RSU dr. Slamet Garut lain dan memilih tetap bertahan pada Unit Rawat Inap Intan Sartika RSU dr. Slamet Garut.

\section{REFERENSI}

[1] S. S. Andaleeb, "Service quality perceptions and patient satisfaction: A study of hospitals in a developing country," Soc. Sci. Med., vol. 52, no. 9, pp. 1359-1370, 2001.

[2] A. Y. Weldetsadik, T. Gishu, A. M. Tekleab, Y. Mekonnen Asfaw, T. Girma Legesse, and T. Demas, "Quality of nursing care and nurses' working environment in Ethiopia: Nurses' and physicians' perception," Int. J. Africa Nurs. Sci., vol. 10, no. March, pp. 131135, 2019.

[3] J. I. Hwang, S. W. Kim, and H. J. Chin, "Patient Participation in Patient Safety and Its Relationships with Nurses' Patient-Centered Care Competency, Teamwork, and Safety Climate," Asian Nurs. Res. (Korean. Soc. Nurs. Sci)., vol. 13, no. 2, pp. 130-136, 2019.

[4] J. H. Y. Ng and B. H. K. Luk, "Patient satisfaction: Concept analysis in the healthcare context," Patient Educ. Couns., vol. 102, no. 4, pp. 790-796, 2019.

[5] J. A. Werthman, "Patient Satisfaction, Nursing, and Radiology: A Review," $J$. Radiol. Nurs., vol. 37, no. 4, pp. 255-259, 2018.

[6] A. Fels, B. Falk, and R. Schmitt, "User-driven Customization and Customer Loyalty: A Survey," Procedia CIRP, vol. 60, pp. 410- 
415, 2017.

[7] J. Sugiat, "Penerapan Strategi Pemasaran Relasional terhadap Pembentukan Nilai Jasa Perguruan Tinggi," Bus. Innov. Entrep. J., vol. 1, no. 1, pp. 21-28, 2019.

[8] R. Setiawan, "Faktor-Faktor yang Mempengaruhi Permintaan Jasa Pariwisata Pemandian Air Panas,” Bus. Innov. Entrep. J., vol. 1, no. 1, pp. 53-61, 2019.

[9] S. C. Chen, "Customer value and customer loyalty: Is competition a missing link?," $J$. Retail. Consum. Serv., vol. 22, pp. 107-116, 2015.

[10] I. Maggioni, "What drives customer loyalty in grocery retail? Exploring shoppers' perceptions through associative networks," $J$. Retail. Consum. Serv., vol. 33, pp. 120-126, 2016. 